\title{
InSITE 2007 Doctoral Consortium Abstract: Information Systems in General Practice: A Framework to Implement the Management and Prevention of Chronic Diseases
}

\author{
Daniel Carbone \\ Victoria University, Melbourne, Australia \\ Daniel.carbone@research.vu.edu.au
}

\begin{abstract}
The detrimental health and economic impacts due to the growth of chronic condition sufferers worldwide is well documented. The practical application of electronic information systems is expected to provide valuable support to this predicament.

The purpose of this study is to develop an information systems implementation framework for the management and prevention of chronic diseases (CD) in general practices (Doctor's surgeries).

Interviews were conducted on key practice personnel where successful CD information systems implementations and adoption occurred. The interviews, in conjunction with the observations of an external IS facilitator to those implementations aimed at corroborating an emerging framework developed from the literature earlier in the study.

Results to this date provided a wealth of information to both part validate and re-design the framework. The role of practice champions, external support, motivators, workflow effects and health outcomes are some of the prominent parameters highlighted in the findings.

The implications, so far in this study have identified commonalities in capacity, processes and implementations flows that affect the framework. However, additional validation on new findings needs to be further explored.
\end{abstract}

Keywords: Information Systems Implementation, Health Information Systems, Chronic Diseases, Information Systems Adoption, General Practice, Practice Champions and Change Management.

Material published as part of this publication, either on-line or in print, is copyrighted by the Informing Science Institute. Permission to make digital or paper copy of part or all of these works for personal or classroom use is granted without fee provided that the copies are not made or distributed for profit or commercial advantage AND that copies 1) bear this notice in full and 2) give the full citation on the first page. It is permissible to abstract these works so long as credit is given. To copy in all other cases or to republish or to post on a server or to redistribute to lists requires specific permission and payment of a fee. Contact Publisher@InformingScience.org to request redistribution permission. 